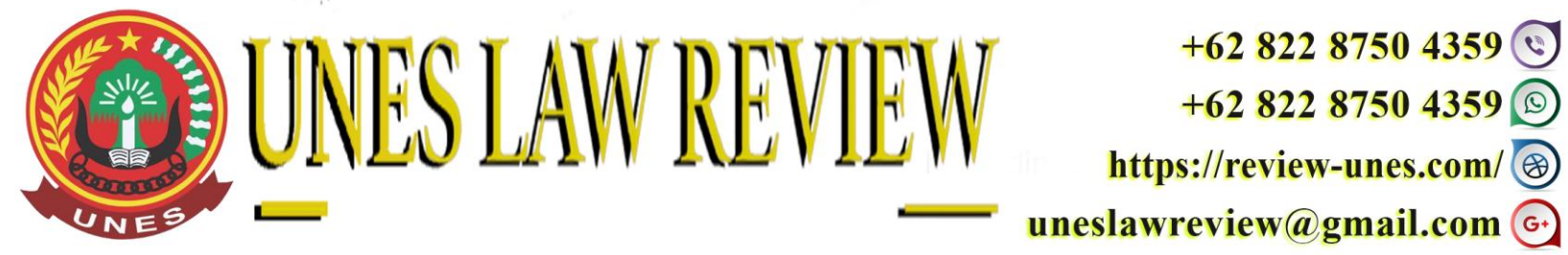

DOI: https://doi.org/10.31933/unesrev.v3i1

Diterima: 17/09/2020, Diperbaiki: 19/09/2020, Diterbitkan: 20/09/2020

\title{
TINJAUAN KRIMINOLOGI TINDAK PIDANA NARKOTIKA YANG DILAKUKAN OLEH ANAK DI WILAYAH HUKUM POLRES 50 KOTA
}

\author{
Besse Patmawanti ${ }^{1}$, Kiki Yulianda ${ }^{2}$ \\ ${ }^{1)}$ Fakultas Hukum, Universitas Ekasakti, Padang, Indonesia. \\ Email: besse_patmawanti@yahoo.com \\ ${ }^{2)}$ Fakultas Hukum, Universitas Ekasakti, Padang, Indonesia. \\ Email: kiki.yulinda@gmail.com
}

Corresponding Author: Penulis ${ }^{1}$ (size 10)

\begin{abstract}
This study examines the Criminology Review of Narcotics Offenses committed by Children in the Legal Area of the 50 City Police. This research is descriptive research. The approach method used in this research is a normative juridical approach as the main approach supported by an empirical juridical approach, using secondary and primary data collected through literature and field studies with data collection techniques through interviews and documentation. The results showed that: 1) by the children in the Legal Area of the 50 City Police, first the factor of lack of parental attention, and feeling isolated so that they fall into narcotics. The second is the environmental factor in which to live and hang out in the community. The third is the factor of curiosity and trial and error that causes this crime of narcotics abuse to occur. Fourth is the factor of education which causes a lack of understanding of the dangers of drugs. 2) The efforts made by the 50 City Police to tackle the Narcotics Crime committed by children, which are divided into 2 efforts, namely Preventive Efforts, which are efforts made by the 50 City Police and carried out before the narcotics crime occurs in the form of campaigns, counseling, socialization. , family approaches, and dissemination of knowledge about the dangers of drugs. Meanwhile, the Repressive Effort is to take action in the form of investigations within the scope of schools and colleges in order to monitor drug trafficking among adolescents.
\end{abstract}

Kata Kunci: Kriminologi, Tindak Pidana Narkotika, Anak

\section{PENDAHULUAN}

Narkotika merupakan obat atau bahan yang bermanfaat di bidang pengobatan, pelayanan kesehatan dan pengembangan ilmu pengetahuan, namun di sisi lain dapat menimbulkan ketergantungan yang sangat merugikan apabila dipergunakan tanpa adanya pengendalian, pengawasan yang ketat dan seksama. Kriminologi kemudian berkembang sebagai ilmu 
pengetahuan ilmiah, yang mana dalam perkembangannya, kriminologi modern terpisah-pisah melandaskan diri pada salah satu cabang ilmu pengetahuan ilmiah tertentu, yaitu sosiologi, hukum, psikologi, psikiatri, dan biologi maka dari itu narkotika juga sangat diperlukan karena keampuhannya menghilangkan rasanyeri di bidang pengobatan (Andi Hamzah dan RM. Surachman, 1994:5). Narkotika merupakan bagian dari narkoba yaitu segolongan obat, bahan atau zat yang jika masuk ke dalam tubuh berpengaruh terutama pada fungsi otak (susunan syaraf pusat) dan sering menimbulkan ketergantungan. Terjadi perubahan dalam kesadaran, pikiran, perasaan, dan perilaku pemakainya (Ahmadi Sofyan, 2007:12).

Berdasarkan Pasal 1 angka (1) Undang-undang Nomor 35 Tahun 2009 tentang Narkotika bahwa narkotika adalah zat atau obat yang berasal dari tanaman atau bukan tanaman, baik sintesis maupun semi sintesis yang dapat menyebabkan penurunan atau perubahan kesadaran, hilangnya rasa, mengurangi sampai menghilangkan rasa nyeri, dan dapat menimbulkan ketergantungan, yang dibedakan ke dalam golongan-golongan sebagaimana terlampir dalam undang-undang ini.

Anak menurut Pasal 1 angka (3) Undang-undang Nomor 11 Tahun 2012 tentang Sistem Peradilan Anak menyebutkan bahwa anak yang berkonflik dengan hukum yang selanjutnya disebut anak adalah anak yang telah berumur 12 (dua belas) tahun, tetapi belum berumur 18 (delapan belas) tahun yang diduga melakukan tindak pidana. Anak memerlukan perlindungan dan pemeliharaan khusus dari orang tuanya. Seperti pada masa sekarang ini telah banyak anak yang mengkonsumsi narkotika, sehingga diperlukan upaya pembinaan dan perlindungan terhadap anak agar anak terhindar dari penyalahgunaan narkotika.

Tindak pidana narkotika merupakan kejahatan, yang secara kriminologis dikategorikan sebagai kejahatan tanpa korban (crime without victim), kejahatan ini tidak diartikan sebagai kejahatan yang tidak menimbulkan korban tetapi mempunyai makna bahwa korban dari kejahatan ini adalah dirinya sendiri. Dengan kata lain, si pelaku sekaligus sebagai korban kejahatan (Made Darma Weda, 1999:80). Kriminologi itu sendiri bararti ilmu pengetahuan yang bertujuan menyelidiki gejala kejahatan seluas-luasnya (Firganefi dan Deni Achmad, 2013:1).

Penerapan sanksi pidana bagi anak yang melakukan tindak pidana narkotika berbeda dengan orang dewasa. Perhitungan pidana yang dijatuhkan kepada anak-anak adalah $1 / 2$ dari maksimum ancaman pidana bagi orang dewasa, karena anak dipandang belum mampu mempertanggungjawabkan perbuatannya secara sepenuhnya. Selain itu, dalam proses penegakan hukum terhadap anak, digunakan beberapa pertimbangan dalam menjatuhkan sanksi pidana tersebut. Teori pertanggungjawaban pidana menjelaskan bahwa pertanggungjawaban pidana ditentukan berdasarkan pada kesalahan pembuat (liability based on fault), dan bukan hanya dengan dipenuhinya seluruh unsur suatu tindak pidana (Sudarto, 1986: 49).

Adanya kasus-kasus ini maka dapat dilihat faktor penyebab terjadinya pengulangan tindak pidana narkotika oleh anak, seperti faktor lingkungan pergaulan yang negatif, faktor keluarga dan faktor ekonomi. Upaya penanggulangan baik secara penal maupun non penal juga telah dilakukan, seperti penyuluhan, rehabilitasi dan pidana penjara. Namun, masih saja kita jumpai kasus tindak pidana narkotika oleh anak. 
Berdasarkan uraian diatas dapat di rumuskan apa yang menjadi permasalahan dalam penelitian ini yaitu:

1. Apakah faktor Penyebab terjadinya Tindak Pidana Narkotika yang dilakukan oleh Anak di Wilayah Hukum Polres 50 Kota?

2. Bagaimanakah upaya yang dilakukanolehPolres 50 Kota untuk menanggulangi Tindak Pidana Narkotikayang Dilakukan Oleh Anak?

\section{METODE PENELITIAN}

Penulisan metode berisikan spesifikasi penelitian, tempat dan waktu, teknik Penelitian ini bersifat deskriptif yaitu suatu usaha untuk menggambarkan dari hal-hal tertentu yang menjadi permasalahan dalam penelitian ini seperti tentang tinjauan kriminologi tindak pidana narkotika yang dilakukan oleh anak di Wilayah Hukum Polres 50 Kota (Fakultas Hukum, 2019:6). Data yang diperoleh dari peneltiian ini, baik data sekunder maupun data primer dikumpulkan dengan cara: 1. Penelitian Kepustakaan (Library Research) \& 2. Penelitian Lapangan (Field Research).

Analisis data yang penulis gunakan dalam penelitian ini adalah secara kualitatif yaitu menganalisa data yang menghasilkan data deskriptif, yang menggambarkan permasalahan dari seputar judul jadi tidak menggunakan angka-angka. Penelitian ini dilakukan di Polres 50 Kota dalam rangka melihat lebih jauh tinjauan kriminologi tindak pidana narkotika yang dilakukan oleh anak.

\section{HASIL DAN PEMBAHASAN}

Faktor-faktor Penyebab terjadinya Tindak Pidana Narkotika yang dilakukanoleh Anak di Wilayah Hukum Polres 50 Kota

Teknologi yang semakin berkembang telah membuat banyak pengaruh terhadap banyak kalangan. Salah satunya narkotika yang telah merebak kemana-mana tanpa memandang status dan usia dimana permasalahan ini telah sangat berbahaya yang menjadi ancaman bagi sebuah Negara karena berpotensi merusak generasi muda penerus bangsa.

Berdasarkan hasil penelitian penulis melalui wawancara denganIbu Bripda Sucy Zelvianaselaku Ba Sat Resnarkoba di Polres 50 Kota ;

"Di kabupaten 50 kota khususnya di kalangan para pelajar sudah banyak yang menyalahi atau melanggar norma-norma, salah satunya ialah pelajar yang menyalahgunakan narkotika. Pelanggaran norma dimulai dari adanya gejala-gejala sosial menyimpang. Gejala sosial yang nampak salah satunya pelajar yang dulunya tidak pernah mengkonsumsi narkotika sekarang ia sudah kecanduan bahkan sampai ketagihan, dengan ketagihannya pelajar tidak mengkonsumsi narkotika akan berdampak pula gejala yang negatif seperti tindak kriminalitas mencuri, merampok dan berkurangnya semangat untuk menjalani aktifitas pembelajaran sehingga mengakibatkan putus sekolah. Penyalahgunaan narkotika yang dilakukan oleh oknum pelajar ini disebabkan oleh beberapa faktor seperti faktor yang berasal dari diri sendiri seperti faktor kepribadian dan faktor rasa ingin tahu. Dan faktor yang berasal dari luar antara lain faktor keluarga, pendidikan, sosial, ekonomi dan lain-lain". 
Penulis telah melakukan penelitian di Polres 50 Kota untuk mengetahui faktor-faktor penyebab terjadinya tindak pidana narkotika yang dilakukan oleh anak di Kabupaten 50 Kota.

Faktor-Faktor Penyebab Penyalahgunaan NarkotikaOleh Anak

\begin{tabular}{|l|l|c|c|}
\hline No & Inisial pelaku & $\begin{array}{c}\text { Faktor-faktor melakukan tidak } \\
\text { narkotika }\end{array}$ & Jenis narkotika \\
\hline 1 & GP & Lingkungan, Keluarga dan coba-coba & ganja \\
\hline 2 & W & Pendidikan, Lingkungan dan coba-coba & ganja \\
\hline
\end{tabular}

Tabel di atas adalah hasil penelitian penulis melalui wawancara yang dilakukan oleh di Polres 50 Kota sebagai berikut:

1. Inisial Nama GP, Umur 17 tahun, Pekerjaan Pelajar dikenakan pasal 127 UU No. 35 Tahun 2009 tentang narkotika. Jenis narkotika yang digunakan adalah ganja.

"Penangkapan GP berawal pada saat unit opsnal resnarkoba Polres 50 Kota sedang melaksanakan patroli seputaran wilayah hukum Polres 50 Kota yaitu di Kecamatan Guguk pada saat itu anggota melihat beberapa pemuda sedang berada didekat rice milling dipinggir jalan tepatnya di Jorong Balai Talang Nagari Guguk VIII KotoKecamatan Guguk Kabupaten 50 Kota. Kemudian anggota opsnal narkoba datang menghampiri salah seorang pemuda yang mengaku bernama GP panggilan G, Kemudian salah seorang anggota melakukan penggeledahan badan sdr $\mathrm{G}$ kemudian ditemukan salah satu lenting diduga narkotika golongan 1 bentuk tanaman jenis daun ganja kering yang dicampur dengan tembakau yang dibungkus dengan kertas papir yang ditemukan ditangan bahagian kirinya, kemudian anggota resnarkoba menanyakan kepada sdr G siapa pemilik daun ganja kering tersebut dan sdr G mengakui bahwa diduga narkotika golongan I bentuk tanaman jenis daun ganja kering tersebut adalah miliknya setelah itu sdr $\mathrm{G}$ dan barang bukti dibawa ke Polres 50 Kota untuk dilakukan pemeriksaan".

GP mengaku menggunakan narkotika dengan alasan faktor lingkungan dan ingin coba-coba yang mana GP diajak oleh temannya yang lebih dewasa sehingga GP masih labil menerima ajakan temannya. Serta faktor keluargayang kurang pengawasan dari kedua orang tua terutama ayah GP yang sibuk dengan pekerjaannya di luar kota yang membawa dampak terhadap anak yang membutuhkan kasih sayang.

2. Inisial Nama W, Umur 17 tahun, Pekerjaan Pelajardikenakan pasal 127 UU No. 35 Tahun 2009 tentang narkotika.Jenis narkotika yang digunakan adalah ganja.

" Penangkapan W berawal dari informasi masyarakat dimana sering terjadi transaksi narkoba dan penyalahgunaan narkotika golongan I jenis daun ganja kering di kawasan Fly Over Kelok Sembilan, untuk memastikan kebenaran informasi tersebut, anggota dari satuan resnarkoba Polres 50 Kota melakukan penyelidikan pada kebenaran informasi tersebut, anggota satuan resnarkoba Polres 50 Kota melakukan penyelidikan pada hari Minggu tanggal 06 mei 2018 sekira pukul 22.45 WIB pada saat sedang melaksanakan patroli seputaran fly over kelok sembilan, anggota dari satuan resnarkoba Polres 50 Kota mencurigai 2 ( dua ) orang laki-laki yang baru keluar dari WC Pos Lantas fly over kelok sembilan, kemudian anggota satuan resnarkoba Polres 50 Kota tersebutmelakukan pengeledahan badan ditemukan 1 ( satu ) paket narkotika golongan I jenis daun ganja kering yang dibungkus dengan lakban 
bewarna kuning pada sdr T,kemudian terhadap saudara $\mathrm{W}$ tidak ditemukan barang bukti padanya.Setelah dilakukan penggeledahan danpenyitaan barang bukti, kemudian ke 2 ( dua ) laki-laki tersebut dibawa ke Polres 50 Kota untuk di proses sesuai dengan hukum yang berlaku."

W Mengaku menggunakan narkotika dengan alasan faktor pendidikan, faktor lingkungan dan ingin coba-coba. W diajak oleh temannya untuk membeli narkotika jenis ganja, karena rendahnya tingkat pendidikan $\mathrm{W}$, yang mana $\mathrm{W}$ sempat berhenti sekolah di tingkat SMP dan saat sekarang melanjutkan kembali pendidikan dengan Paket B setingkat dengan SMPsehingga membuat $\mathrm{W}$ tidak dapat memikirkan dampak perbuatannya yang dapat merugikan dirinya, keluarga dan orang lain.

Melihat data dan uraian pada tabeldiatas tentang faktor-faktor penyebab tindak pidana narkotika, maka penulis mencoba menguraikan beberapa faktor penyebab tindak pidana narkotika yang dilakukan oleh anak.

1. Faktor internal

Faktor internal sebagai faktor yang berasal dari dalam diri si pelaku yang berupa:

a. Faktor kepribadian

Faktor kepribadian yang lemah, tidak mempunyai sifat dan sikap yang tegas, terlalu mudah untuk ikut dalam pergaulan teman-teman apalagi bila mempunyai teman dekat yang salah pergaulan akan menyebabkan kepribadiannya berubah mengikuti teman dekatnya tersebut.

b. Faktor rasa ingin tahu dan keinginan untuk mencoba

Semua orang memiliki rasa ingin tahu bahkan untuk sesuatu hal yang tidak harus diketahui. Mencoba sesuatu hal adalah usaha untuk mencari tahu. Sama halnya dengan mencoba narkotika awalnya hanya ingin tahu bagaimana rasa narkotika tersebut.

\section{Faktor Eksternal}

a. Faktor Keluarga

Faktor keluarga, terutama faktor orangtua yang sering ikut menjadi penyebab seorang anak menjadi penyalahguna narkotika antara lain:

- Orangtua yang kurang komunikasi dengan anaknya

- Orangtua yang kurang harmonis, sering bertengkar atau orangtua berselingkuh

- Orangtua atau salah satu anggota keluarga yang menjadi penyalahguna narkotika

b. Faktor Pendidikan

Banyak dari mereka yang putus sekolah. Sehingga pemahaman mereka tentang bahaya narkoba tidak diketahui dengan baik.

c. Faktor Lingkungan

Anak tidak hanya hidup di dalam lingkup keluarga dan di sekolah saja, melainkan juga dalam lingkunganmasyarakat luas. Oleh karena itu, pergaulan anak dengan masyarakat juga mempengaruhi perilaku anak, termasuk perilaku yang berkaitan dengan penyalahgunaan narkotika. 
d. Faktor ekonomi

Sulitnya lapangan pekerjaan disertai kebutuhan sehari-hari yang terus meningkat menjadi penyebab seseorang mau melakukan apa saja untuk mendapatkan uang dengan cepat dan banyak, walaupun mereka tahu pekerjaan tersebut melanggar hukum.

\section{Upaya-upaya yang dilakukan oleh untuk menanggulangi Tindak Pidana Narkotika yang dilakukan oleh Anak di Wilayah Hukum Polres 50 Kota}

Berdasarkan hasil penelitian penulis melalui wawancara dengan Ibu Bripda Sucy Zelviana selaku Ba Sat Resnarkoba di Polres 50 Kota menjelaskan bahwa; masalah tindak pidana narkotika yang dilakukan oleh Anak akan terpecahkan apabila dilakukan dengan upaya menanggulangi tindak pidana narkotika dikalangan anak dengan cara melakukan upaya preventif dan upaya represif. Upaya preventif sendiri merupakan sebuah upaya yang dilakukan Kepolisian Polres 50 Kota sebelum tindak pidana terjadi. Sementara itu upaya represif adalah suatu tindakan aktif yang dilakukan pihak Kepolisian Polres 50 Kota pada saat penyimpangan sosial telah terjadi.

Adapun penegakan hukum terhadap pelaku tindak pidana narkotika (psikotropika maupun narkotika dan obat-obatan terlarang) yang dilakukan oleh Kepolisian Polres 50 Kota menunjukkan bukti keseriusan guna menanggulangi tindak pidana tersebut.

Berdasarkan temuan tindak pidana narkoba diatas perlu adanya penanggulangan agar tidak berlanjut dan menjadi lebih parah khususnya di kalangan anak. Hal inilah yang menarik perhatian Kepolisian Polres 50 Kota untuk melaksanakan upaya guna menanggulangi tindak pidana narkotika khusunya di kalangan anak, strategi yang dilaksanakan adalah stratergi pencegahan (preventif) dan penindakan (represif).

1. Upaya Preventif

Upaya preventif adalah sebuah upaya yang dilakukan Kepolisian Polres 50 Kota dan dilakukan sebelum tindak pidana narkotika terjadi dalam bentuk kampanye, penyuluhan, sosialisasi, pendekatan pada keluarga, dan penyebaran pengetahuan mengenai bahaya narkoba. Cara ini dilakukan diberbagai kelompok masyarakat seperti sekolah, dari tingkat Sekolah Dasar (SD) sampai Sekolah Menengah Atas (SMA), hingga perguruan tinggi, bahkan juga dilakukan dibeberapa perkampungan wilayah hukum 50 Kota.

Berikut ini adalah upaya yang telah dilakukan oleh Kepolisian Polres 50 Kota dalam menanggulangi tindak pidana narkotika di kalangan anak:

a. Sosialisasi di Kalangan Pelajar dan Mahasiswa

Berikut ini adalah hasil wawancara dengan Bapak IPTU Hendri Has, S.H. selaku Kasat Resnarkoba Polres 50 Kota;

"Untuk upaya preventif kami mengadakan sosialisasi di sekolah-sekolah, baik SD, SMP maupun SMA. Kami melakukan sosialisai mengenai himbauan untuk jangan sekali-kali memakai narkoba. Program ini diharapkan akan memberikan manfaat untuk dapat menggungah semangat pelajar danmahasiswa untuk turut aktif sebagai garis depan untuk melawan narkoba di kalangan remaja." 
Berdasarkan hasil wawancara di atas dapat penulis simpulkan bahwa kegiatan sosialisasi bertujuan untuk mempengaruhi para remaja khususnya di kalangan terpelajar untuk tidak mencoba narkoba, dengan demikian tercipta suatu kesadaran, kewaspadaan, dan daya tangkal agar para remaja memiliki sikap tegas untuk tidak melakukan penyalahgunaan narkoba.

b. Penyuluhan dan Pendekatan pada Masyarakat

Berikut ini adalah hasil wawancara dengan Bapak IPTU Hendri Has,S.H. selaku Kasat Resnarkoba Polres 50 Kota;

"Kami juga mendatangi perkampungan, Karang Taruna, kemudian di Kelurahan kami kumpulkan. Kami juga bekerjasama dengan SATBINMAS (Satuan Bina Masyarakat), dengan harapan kami dapat melakukan pendekatan secara langsung pada pihak keluarga."

Berdasarkan hasil wawancara di atas dapat penulis simpulkan bahwa dengan penyuluhan tersebut maka akan terjadi transfer informasi dari pihak Kepolisian kepada masyarakat khususnya orang tua mengenai bahaya narkoba, sehingga orang tua atau keluarga dapat menjaga anak-anaknya dari bahaya penyalahgunaan narkoba.

c. Operasi Rutin

Berikut ini adalah hasil wawancara dengan Bapak IPTU Hendri Has, S.H. selaku Kasat Resnarkoba Polres 50 Kota;

"Kami telah melaksanakan koordinasi dengan Balai POM untuk mengadakan razia maupun pemeriksaan di toko-toko obat maupun apotek, kemudian di sekolah dan warung-warung di sekitar sekolah. Kemudian yang menjadi sasaran juga, yang tidak kalahpentingnya di tempat hiburan".

Berdasarkan hasil wawancara di atas, peneliti dapat menyimpulkan bahwa Kepolisian Polres 50 Kota sangat gencar dalam melakukan upaya menanggulangi tindak pidana narkotika khusunya di kalangan anak ini, terbukti dengan dilakukannya operasi rutin yang dilakukan diberbagai tempat, bahkan di sekolah, dan tempat hiburan malam dimana di sana terdapat anak atau remaja yang dalam hal ini sangat rentan menjadi sasaran tindak pidana narkotika.

d. Melakukan Kerjasama dengan Masyarakat, Lembaga dan Organisasi.

Berikut ini adalah hasil wawancara dengan Bapak IPTU Hendri Has, S.H. selaku Kasat Resnarkoba Polres 50 Kota;

"Selain SATBINMAS, kami juga melakukan kerjasama dengan LSM, sepeti yang sudah terbentuk adalah GRANAT (Gerakan Anti Narkoba), ada juga yang baru saja terbentuk ya ini, namanya Gerakan Selamatkan Negeri, yang sudah terbentuk di wilayah hukum 50 Kota”.

Berdasarkan hasil wawancara di atas, dapat penulis simpulkan bahwa hal yang tak kalah penting dalam upaya penanggulangan tindak pidana narkotika di kalangan anak adalah adanya peran serta masyarakat lain di luar penegak hukum itu sendiri. Terbentuknya kerjasama antara Kepolisian dengan beberapa organisasi, lembaga, 
instansi, dan/atau tokoh masyarakat merupakan langkah Kepolisian Polres 50 Kota guna peningkatan kesadara dan ketaatan masyarakat terhadap hukum dan ketentuan perundang-undangan serta terpeliharanya keamanan dan ketertiban.

\section{Upaya Represif}

Terkait penindakan represif Kepolisian Polres 50 Kota melakukan penindakan berupa penyelidikan di lingkup sekolah dan perguruan tinggi dalam rangka mengawasi peredaran narkoba di kalangan remaja. Seperti yang disampaikan oleh Bapak IPTU Hendri Has, S.H. selaku Kasat Resnarkoba Polres 50 Kota pada hasil wawancara berikut ini:

"Kami melakukan tindakan lidik, yaitu penyelidikan yang kami lakukan di sekolah dan bahkan perguruan tinggi. Disamping kami mendapat informasi kami juga melaksanakan penyelidikan apabila ditemukan pelaku penyalahgunaan narkoba."

Dapat penulis simpulkan bahwa dalam hal ini Kepolisian Polres 50 Kota telah melakukan fungsi penegakan hukum. Peranan penegak hukum salah satunya ialah bagaimana mengaktualisasikan secara nyata, aturan-aturan hukum bisa terwujud dalam kaidah-kaidah sosial masyarakat. Sebagai suatu sarana untuk menegakkan hukum diantaranya ialah dengan penerapan sanksi pidana. Perumusan norma-norma pidana telah diatur dalam Undang-undang Nomor 35 Tahun 2009, berikut konsep penetapan sanksi pidana. Dalam undang-undang tersebut, untuk menentukan kategorisasi sanksi pidana lebih ditentukan oleh jenis-jenis penggolongan narkotika yang dilanggar, seyogyanya pemerintah mengatur tentang batas maksimal jumlah narkotika yang disimpan, digunakan, dimiliki, secara tidak sah sehingga dapat membedakan pelaku tindak pidana, apakah digolongkan sebagai pemilik, pengguna atau pengedar.

\section{KESIMPULAN}

Berdasarkan hasil penelitian diatas, dapat disimpulkan sebagai berikut;

1. Dalam melaksanakan tinjauan kriminologi tentang tindak pidana narkotika yang dilakukan oleh Anak di Wilayah Hukum Polres 50 Kota, Pertama faktor kurang perhatian orang tua, dan merasa terasingkan sehingga terjerumus kedalam narkotika. Keduaadalah faktor lingkungan dimana tempat tinggal dan bergaul dalam masyarakat. Ketiga adalah faktor rasa penasaran dan coba-cobayang menyebabkan tindak pidana penyalahgunaan narkotikaini terjadi.Keempatadalah faktor pendidikan yang menyebabkan kurangnya pemahaman tentang bahaya narkoba.

2. Upaya-upaya yang dilakukan olehPolres 50 Kota untuk menanggulangi Tindak Pidana Narkotika yang dilakukan oleh Anakyaitu terbagi atas 2 upaya yaitu Upaya Preventif adalah sebuah upaya yang dilakukan Kepolisian Polres 50 Kota dan dilakukan sebelum tindak pidana narkotika terjadi dalam bentuk kampanye, penyuluhan, sosialisasi, pendekatan pada keluarga, dan penyebaran pengetahuan mengenai bahaya narkoba. Melakukan Sosialisasi di Kalangan Pelajar dan Mahasiswa, Penyuluhan dan Pendekatan pada Masyarakat, Operasi Rutin, Melakukan Kerjasama dengan masyarakat, lembaga dan organisasi. Sedangkan Upaya 
Represif yaitu melakukan penindakan berupa penyelidikan di lingkup sekolah dan perguruan tinggi dalam rangka mengawasi peredaran narkoba di kalangan remaja.

\section{DAFTAR PUSTAKA}

Andi Hamzah dan RM. Surachman, Kejahlmtan Narkotika dan Psikotropika, Sinar Grafika, Jakarta 1994.

Ahmadi Sofyan, Narkoba Mengincar Anak Muda, Prestasi Pustaka, Jakarta 2007.

Fakultas Hukum, Pedoman Penyusunan Usulan Penelitian dan Skripsi, Universitas Ekasakti, Padang, 2019.

Firganefi dan Deni Achmad. Hukum Kriminologi, PKKPUU FH UNILA, Bandar Lampung 2013.

Made Darma Weda. Kronik dalam Penegakan Hukum Pidana, Guna Widya, Jakarta 1999.

Sudarto. Kapita Selekta Hukum Pidana, Alumni, Bandung 1986.

Undang-undang Republik Indonesia Nomor 35 Tahun 2009 tentang Narkotika

Undang-undang Republik Indonesia Nomor 11 Tahun 2012 tentang Sistem Peradilan Anak 